\title{
Relevansi Delimitasi Perbatasan Maritim Dengan Faktor Lingkungan
}

\section{Evi Purwanti}

Fakultas Hukum Universitas Tanjungpura, Pontianak, Indonesia

@ : evi.purwanti@hukum.untan.ac.id

: $\operatorname{xxxxxxxxxxxxx}$

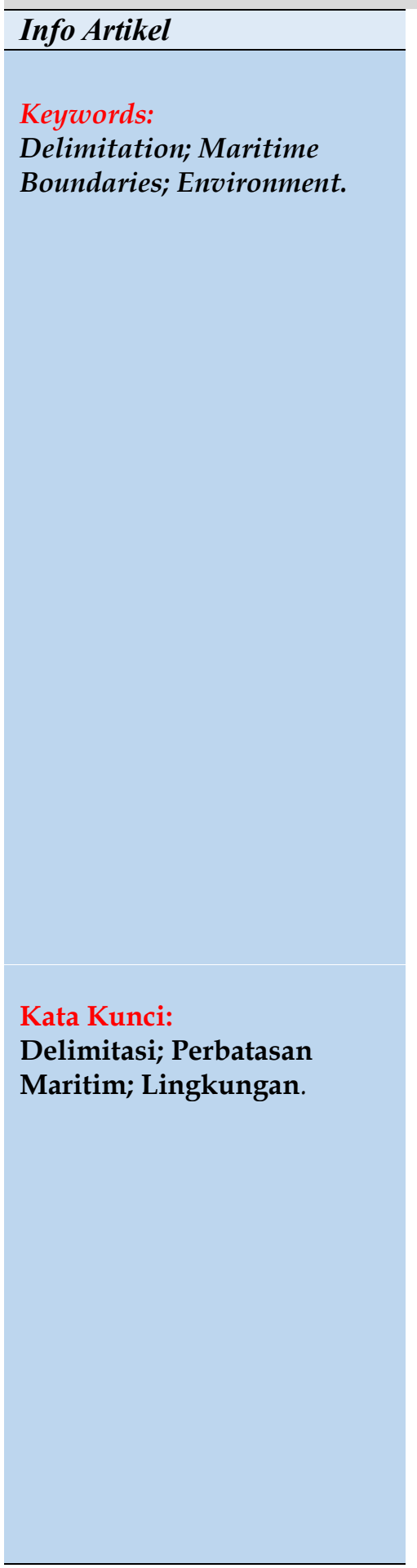

\begin{abstract}
Introductioan: This article discusses the relevance of maritime border delimitation with environmental factors that affect the determination of delimitation.

Purposes of the Research: The purpose of this study is to analyze the urgency of the role of the environment in the maritime border delimitation process. Specifically focused on analyzing whether there is a positive relationship between environmental considerations and the development of the delimitation process and to determine the environmental factors that influence the delimitation.

Methods of the Research: This research uses normative research with a conceptual approach. Researchers use relevant environmental law concepts in the maritime border delimitation process.

Results of the Research: The results of the study show that there is a relevance of environmental factors in determining maritime border delimitation, among others from factors: conservation of wildlife reserves, the principle of natural prolongation, the principle of sustainable development, mineral resources, and fisheries. The relationship between environmental factors and the delimitation process occurs in two ways: First, environmental considerations show a direct influence in the selection of the delimitation method. Here environmental factors are an important motive in the delimitation process. Second, environmental factors affect the delimitation process indirectly where there are a number of delimitation agreements that do not include specific provisions regarding the environment, but the evidence shows that the parties are motivated by environmental factors in negotiating delimitation.
\end{abstract}

\footnotetext{
Abstrak

Latar Belakang: Artikel ini membahas tentang relevansi delimitasi perbatasan maritim dengan faktor lingkungan yang mempengaruhi penentuan delimitasi.

Tujuan Penelitian: Tujuan penelitian ini untuk menganalisis urgensi peran lingkungan dalam proses delimitasi perbatasan maritim. Secara khusus difokuskan pada analisis apakah ada hubungan yang positif antara pertimbangan lingkungan dengan perkembangan proses delimitasi serta untuk mengetahui apa saja faktor lingkungan yang berpengaruh tersebut.

Metode Penelitian: penelitian ini menggunakan jenis penelitian normatif dengan pendekatan konsep hukum (conceptual approach). Peneliti menggunakan konsep hukum lingkungan yang relevan dalam proses delimitasi perbatasan maritim.

Hasil Penelitian: Hasil penelitian menunjukan bahwa terdapat relevansi faktor lingkungan dalam penentuan delimitasi perbatasan maritim, antara lain dari faktor: konservasi suaka margasatwa, prinsip perpanjangan alami (principle of natural
} 
prolongation), the principle of sustainable development, Sumber daya mineral, dan perikanan. Hubungan antara faktor lingkungan dengan proses delimitasi terjadi dengan dua cara: Pertama, pertimbangan lingkungan menunjukkan pengaruh langsung dalam pemilihan metode delimitasi. Disini faktor lingkungan merupakan motif yang penting dalam proses delimitasi. Kedua, faktor lingkungan mempengaruhi proses delimitasi secara tidak langsung di mana ada sejumlah perjanjian delimitasi yang tidak mencantumkan secara spesifik ketentuan mengenai lingkungan, tapi bukti-bukti menunjukkan bahwa para pihak dimotivasi oleh faktor lingkungan dalam melakukan negosiasi delimitasi.

\section{A. PENDAHULUAN}

Perbatasan bagi suatu negara merupakan unsur yang krusial, dimana perbatasan yang mengelilingi negara merupakan tonggak atau simbol yang menandai dimulainya kedaulatan suatu negara dan jika telah melewati batas negara itu maka berakhirlah kewenangan dan yurisdiksi negara tersebut. Kewenangan suatu negara di wilayah lautnya meliputi eksplorasi, eksploitasi, konservasi dan pengelolaan kekayaan laut serta penegakan keamanan dan kedaulatan negara. Dengan besarnya tanggungjawab dan kewenangan negara maka penting untuk mengetahui sampai batas mana kedaulatan suatu negara dapat ditegakkan.

Sengketa batas internasional telah menjadi ciri hubungan internasional sejak zaman dahulu. Sengketa batas laut jauh lebih kompleks daripada sengketa di darat. Kompleksitas ini sebagian besar karena penanda batas laut, terutama garis dasar hidrografi, dapat dengan mudah berubah karena proses pengendapan dan erosi pantai yang telah meningkat oleh perubahan iklim. Di seluruh dunia, sengketa batas laut menimbulkan tantangan besar bagi tatanan yang ada. Tidak ada benua yang bebas dari perselisihan seperti itu. ${ }^{1}$

Untuk menentukan perbatasan maritim antar negara maka perlu dilakukan delimitasi. Proses delimitasi merupakan suatu penentuan garis batas di wilayah maritim yang berbatasan langsung dengan negara lain baik itu yang berdampingan ataupun berseberangan. Penentuan delimitasi perbatasan maritim dipengaruhi dan berinteraksi dengan beberapa isu seperti politik, faktor historis dan kebudayaan, isu strategis dan keamanan, kepentingan ekonomi, dan kepentingan bagi kelompokkelompok masyarakat. Pentingnya nilai yang terkandung dalam delimitasi maritim serta kompleksitas proses yang terkait dalam penentuan delimitasi maritim membuat topik ini menjadi objek penelitian yang populer dalam hukum internasional.

Penetapan batas laut merupakan proses yang kompleks dan multifaset dengan aspek hukum dan teknis. Prosesnya melibatkan penentuan batas maritim dalam situasi di mana dua atau lebih negara dihadapkan dengan klaim yang tumpang tindih. Dengan tidak adanya aturan yang tepat dalam hukum perjanjian dan aturan kebiasaan yang ditetapkan berdasarkan praktik negara, telah diserahkan kepada yurisprudensi pengadilan dan tribunal internasional untuk mengembangkan hukum delimitasi batas

${ }^{1}$ Christ O. Ikporukpo, "Boundaries and Natural Resources in the Sea," The Journal of Territorial and Maritime Studies Vol 7, no. 2 (2020): 103-27.

77 | B A L O B E Law Journal Vol. 1 No. 2, Oktober 2021 
laut yang berlaku. ${ }^{2}$

United Nations Convention on the Law of the Sea 1982 (UNCLOS 1982) menetapkan rezim hukum dan ketertiban yang komprehensif di lautan dan samudera dunia yang menetapkan aturan yang mengatur semua penggunaan lautan dan sumber dayanya. Konvensi ini mengabadikan gagasan bahwa semua masalah ruang laut saling terkait erat dan perlu ditangani secara keseluruhan. Konvensi dibuka untuk ditandatangani pada 10 Desember 1982 di Montego Bay, Jamaika. Ini menandai puncak dari lebih dari 14 tahun kerja yang melibatkan partisipasi lebih dari 150 negara yang mewakili semua wilayah di dunia, semua sistem hukum dan politik dan spektrum pembangunan sosial/ekonomi. Pada saat diadopsi, Konvensi tersebut diwujudkan dalam satu instrumen aturan tradisional untuk penggunaan lautan dan pada saat yang sama memperkenalkan konsep dan rezim hukum baru dan menangani masalah baru. Konvensi ini juga memberikan kerangka kerja untuk pengembangan lebih lanjut dari wilayah hukum laut tertentu. Konvensi mulai berlaku sesuai dengan pasal 308 pada tanggal 16 November 1994, 12 bulan setelah tanggal penyimpanan instrumen ratifikasi atau aksesi keenam puluh. Saat ini, rezim yang diakui secara global menangani semua hal yang berkaitan dengan hukum laut. Konvensi (teks lengkap) terdiri dari 320 pasal dan sembilan lampiran, yang mengatur semua aspek ruang laut, seperti delimitasi, pengendalian lingkungan, penelitian ilmiah kelautan, kegiatan ekonomi dan komersial, alih teknologi dan penyelesaian sengketa yang berkaitan dengan masalah laut. $^{3}$

Berdasarkan UNCLOS 1982 negara pantai memiliki bentuk kedaulatan yang berbeda dalam masing-masing zona laut. Untuk perairan pedalaman, perairan kepulauan dan laut teritorial memiliki kedaulatan mutlak (sovereignty), sedangkan untuk zona tambahan, zona ekonomi eksklusif dan landas kontinen hanya sebatas hak berdaulat (sovereign rights) untuk eksplorasi dan eksploitasi sumber kekayaan lautan. Hal ini merupakan salah satu bentuk pertimbangan masyarakat internasional dalam pembagian sumber kekayaan alam yang lebih adil dan merata bagi masing-masing negara baik itu negara pantai maupun negara yang tidak berpantai agar mendapat manfaat sebesar-besarnya dari sumber daya laut untuk kepentingan umat manusia.

Penciptaan zona laut ini membawa akibat perlunya delimitasi zona yang berbatasan ketika negara-negara mempermasalahkan perbatasannya. Peran UNCLOS 1982 sangat penting dalam penentuan proses delimitasi karena UNCLOS 1982 memuat ketentuan-ketentuan mengenai delimitasi tiap zona maritim yang telah diakui keberadaannya oleh masyarakat internasional. Dalam proses delimitasi UNCLOS 1982 memberi kewenangan yang besar kepada negara-negara peserta dengan memberi kebebasan bersepakat antara para pihak untuk menentukan batasbatas antar negara yang berhadapan langsung atau yang berdampingan. Hal ini tidak terlepas dari tujuan UNCLOS 1982 agar dapat disetujui oleh sebanyak-banyaknya negara di dunia, dengan tidak mengurangi kedaulatan dari negara sebagai penentu

2 Yunus Emre Acikgonul and Edward R. Lucas, "Developments in Maritime Delimitation Law over the Last Decade: Emerging Principles in Modern Case Law," Canadian Yearbook of International Law 45, no. 3 (2020), https:/ / doi.org/10.1017/cyl.2020.9.

3 Hannes Hansen-Magnusson, "The UN Convention on the Law of the Sea," in International Relations as Politics among People, 2020, https://doi.org/10.4324/9780429197413-4.

78 B A L OB E Law Journal Vol. 1 No. 2, Oktober 2021 
kekuasaan tertinggi negara.

Penentuan delimitasi perbatasan maritim dilihat dari berbagai faktor yang mempengaruhi perjanjian penentukan perbatasan yang bersebelahan ataupun berseberangan antara kedua negara. Proses delimitasi merupakan suatu rangkaian kegiatan yang komprehensif, serta melibatkan banyak pihak, seperti para diplomat, pakar geografi, hidrografi, geologi, ahli hukum, sosial, ekonomi, lingkungan, dan lainlain. Terdapat beberapa prinsip dan metode dalam penentuan delimitasi. Selain itu terdapat juga faktor-faktor penting yang mempengaruhi delimitasi seperti aspek geografi, ekonomi, sosial, politik, teknologi dan lingkungan.

Melihat banyaknya faktor yang berpengaruh dalam delimitasi perbatasan maritim maka peneliti tertarik untuk membahas salah satu faktor yang menentukan proses delimitasi maritim tersebut. Fokus utama penelitian ini adalah mengenai peran lingkungan dalam penentuan delimitasi perbatasan maritim. Mengingat permasalahan lingkungan merupakan suatu masalah yang universal dan salah satu topik yang hangat didiskusikan dalam forum internasional maka penting untuk mengkaji sampai seberapa jauh faktor lingkungan berperan dalam proses delimitasi.

\section{B. METODE PENELITIAN}

Berdasarkan jenisnya penelitian ini menggunakan jenis penelitian normatif dengan pendekatan konsep hukum (conceptual approach). Peneliti menggunakan konsep hukum lingkungan yang berkaitan dan berguna dalam proses delimitasi perbatasan maritim. Alat penelitian yang dipergunakan adalah studi dokumen atau bahan pustaka. Data dikumpulkan dengan melakukan studi dokumen.

\section{HASIL DAN PEMBAHASAN}

Dominice menyatakan bahwa hukum internasional secara umum adalah hukum internasional universal, atau biasa dinyatakan sebagai aturan dan prinsip hukum umum. Prinsip hukum umum ini tercantum dalam Statuta Mahkamah Internasional Pasal 38 para. 1 (c), serta hukum kebiasaan internasional yang termasuk ke dalam prinsip-prinsip hukum internasional. Salah satu prinsip yang telah diaplikasikan oleh Mahkamah Internasional dan telah dikenal sebagai prinsip hukum umum adalah: "Where development may cause significant harm to the environmen there is a duty to prevent, or at least to mitigate, such harm...". ${ }^{4}$

Prinsip di atas merupakan perpaduan dari keharusan untuk melindungi lingkungan dan kebutuhan untuk membangun. ide tersebut memberikan kontribusi yang besar terhadap pentingnya penggabungan prinsip pembangunan berkelanjutan dan bagaimana penerapan konkretnya dilapangan. Prinsip lingkungan ini tidak memformulasikan secara langsung hak dan kewajiban negara-negara secara spesifik. Prinsip pembangunan berkelanjutan ini harus diaplikasikan secara nyata, dengan mempertimbangkan semua keadaan, hukum dan kenyataan yang ada dilapangan.

Jika dibandingkan dengan faktor-faktor seperti geografi, navigasi, sosial, politik, teknologi dan ekonomi maka faktor lingkungan memiliki peran yang lebih kecil

4 T.M. Ndiaye and R Wolfrum, Law of the Sea, Environmental Law and Settlement of Disputes (Leiden/Boston: Martinus Nijhoff Publishers, 2007).

79 | B A L OBE Law Journal Vol. 1 No. 2, Oktober 2021 
dalam mempengaruhi penentuan perjanjian delimitasi maritim. Berdasarkan putusanputusan Pengadilan Internasional faktor dominan yang mempengaruhi delimitasi adalah faktor geografi negara pantai yang berkepentingan. Di beberapa perjanjian perbatasan ada yang ikut serta mempertimbangkan faktor lingkungan, namun ada juga perjanjian perbatasan yang mengabaikan faktor lingkungan ini.

Perhatian para pihak terhadap lingkungan tercermin di dalam ketentuan khusus di sejumlah perjanjian. Sebagai contoh faktor lingkungan terdapat dalam perjanjian multi purpose antara Australia dan Papua New Guinea di dalam Torres Strait Treaty tahun 1978. pengaturan tentang lingkungan juga terdapat di dalam beberapa perjanjian yang mengandung resource deposit clauses dan/ atau ketentuan untuk joint development arrangements. ${ }^{5}$

Dalam hukum internasional, Mahkamah Internasional memainkan peran penting dalam perkembangan kriteria untuk menentukan delimitasi batas maritim antara negara-negara yang bertetangga. Prinsip dasarnya adalah: "the delimitation is to be effected by agreement in accordance with equitable principle and by taking account of all the relevant circumstances in order to achieve an equitable solution." Perdebatan pengadilan internasional masih terus berlanjut mengenai bagaimana mengidentifikasikan dan meng-aplikasikan equitable principle atau relevant circumstances dalam rangka untuk mencapai hasil yang equitable. Penekanan terbesar kepada pertimbangan geografi yang memainkan peran utama dan penting dalam proses delimitasi. ${ }^{6}$

Hubungan antara faktor lingkungan dengan delimitasi dapat meliputi beberapa cara. Dapat diyakini bahwa terdapat natural boundary dalam lingkungan laut yang membagi dua ekosistem yang berbeda dan dapat membentuk legal boundary. Argumen lain menyatakan bahwa delimitasi harus menghormati prinsip equitable yang membutuhkan penerapan faktor lingkungan. ${ }^{7}$ Amerika Serikat mengidentifikasi dua prinsip itu ketika mengomentari kasus the Gulf of Maine. Isinya yaitu delimitasi harus memfasilitasi konservasi dan manajemen sumber daya alam serta memperkecil potensi sengketa internasional. Pendapat pertama itu berhubungan dengan konsep kesatuan deposit sumber daya alam (unity of resource deposit), namun para hakim Mahkamah Internasional tidak menganggap relevan prinsip-prinsip ini secara hukum. ${ }^{8}$

Meskipun demikian, tidak berarti lingkungan tidak memainkan peran dalam proses delimitasi maritim. Para ahli mempercayai bahwa beberapa wilayah laut membentuk suatu unit tunggal lingkungan yang terintegrasi. Mereka juga membicarakan mengenai natural boundaries di perairan laut. Terdapat kemungkinan untuk membuat garis lokasi yang membedakan species individual atau stok

${ }^{5}$ Barbara Kwiatkowska, "Economic and Environmental Considerations in Maritime Boundary Delimitation," in International Maritime Boundaries, ed. Jonathan I. Charney and Lewis M. Alexander (Netherlands: Martinus Nijhoff Publishers, 1996).

${ }^{6}$ Surya P. Sharma, "Relevance of Environmental and Security Considerations to the Delimitation of Maritime Boundaries," in Law, Social Sciences and Public Policy Towards a Unified Framework, ed. Anthony Chin and Alfred Choi (Singapore: Singapore University Press, 1998).

7 Kwiatkowska, "Economic and Environmental Considerations in Maritime Boundary Delimitation."

8 "I.C.J Reports," 1984.

80 | B A LOBE Law Journal Vol. 1 No. 2, Oktober 2021 
perikanan. Terdapat kemungkinan hubungan antara aktivitas di daratan dengan sumber kekayaan lautan. Sebagai contoh, polusi laut yang bersumber dari daratan dapat secara langsung mempengaruhi sumber daya laut dan eksploitasinya. Di lain sisi aktivitas laut di wilayah yang spesifik dapat secara langsung mempengaruhi struktur tanah di daratan. ${ }^{9}$

Untuk mengetahui lebih lanjut relevansi delimitasi perbtaasan maritim dengan faktor lingkungan maka di bawah ini akan dipaparkan mengenai beberapa faktor lingkungan yang dapat mempengaruhi dan menjadi pertimbangan para pihak yang melakukan delimitasi perbatasan maritim.

\section{Konservasi Suaka Margasatwa}

Salah satu faktor dalam hukum lingkungan yang dapat menjadi alasan dalam melakukan klaim atau untuk memperkuat argumen terhadap suatu pulau yang sebenarnya tidak layak untuk dijadikan titik poin atau diberi kewenangan penuh (full effect) yaitu dengan alasan bahwa pulau tersebut merupakan konservasi suaka margasatwa.

Sebagai contohnya dapat dilihat dari argumen Venezuela terhadap lingkungan yang secara eksplisit di sebutkan dalam konteks garis perbatasan secara aktual, berkaitan dengan Aves Island dalam delimitasi maritim dengan Perancis (Guadaloupe and Martinique) tahun 1980, dengan Belanda (Antilles) tahun 1978, dan dengan Amerika tahun 1978. Venezuela menyatakan bahwa Aves Island secara ekonomi dapat berhasil, berdasarkan panen guano (artinya dalam bahasa Spanyol: yaitu pupuk dari kotoran burung atau kelelawar pada pertengahan abad yang lalu). Venezuela memajukan argumen tersebut untuk memberikan alasan yang tepat terhadap penetapan full effect terhadap Aves Island yang tidak bisa dihuni. Alasan baru lain yang berkaitan dengan lingkungan yang diajukan oleh Venezuela adalah berkaitan dengan konservasi Aves Island sebagai suaka margasatwa. Jika dilihat secara keseluruhan, peran full effect yang diberikan kepada Aves Island antara Venezuela dengan negara Belanda, ${ }_{10}$ harus dipandang sebagai bagian paket kesepakatan yang didesain untuk memelihara hubungan politik dan ekonomi yang baik. Mungkin perjanjian perbatasan di atas tidak merefleksikan secara nyata pengaruh dari permasalahan lingkungan dalam penentuan garis perbatasan (boundary line). ${ }^{11}$ Namun dapat dicatat bahwa alasan lingkungan dapat dimajukan sebagai argumen dalam memperkuat posisi klaim atas delimitasi maritim suatu negara.

Dalam kasus Sipadan Ligitan peran konservasi suaka margasatwa ini muncul secara tidak langsung. Dalam sengketa antara Indonesia dan Malaysia mengenai kepemilikan pulau Sipadan dan Ligitan yang diajukan ke Mahkamah Internasional, para hakim akhirnya memutuskan bahwa Malaysia yang berhak memiliki pulau tersebut. Sehubungan dengan prinsip effectivities yang menjadi dasar para hakim memutuskan perkara pada pulau Sipadan dan Ligitan, Malaysia menyebutkan

9 Jonathan I. Charney, "Ocean Boundaries between Nations: A Theory for Progress," American Journal of International Law 78 (1984).

${ }_{10}$ Arbitral award relating to the issue of control and sovereignty over Aves island, raised between Venezuela and the Kingdom of the Netherlands (n.d.).

11 Kwiatkowska, "Economic and Environmental Considerations in Maritime Boundary Delimitation."

81 B A L OBE Law Journal Vol. 1 No. 2, Oktober 2021 
kontrol atas pengambilan penyu dan pengumpulan telur penyu, yang diduga merupakan kegiatan ekonomi yang paling penting pada Sipadan selama bertahuntahun. Malaysia juga mendasarkan pada pembentukan sebuah cagar alam burung di Sipadan pada tahun 1933. Malaysia lebih lanjut menunjukkan bahwa pemerintah kolonial Inggris Kalimantan Utara membangun mercusuar di Pulau Sipadan Ligitan di awal 1960-an dan mercusuar itu tetap ada sampai hari ini dan dipertahankan oleh otoritas Malaysia. ${ }^{12}$ Dalam kasus ini meskipun prinsip utama yang digunakan oleh mahkamah Internasional adalah effectivities namun peran lingkungan dalam hal ini konservasi suaka margasatwa dipaparkan juga sebagai bukti pendukung prinsip effectivities tersebut.

\section{Prinsip Perpanjangan Alami (natural prolongation)}

Pasal 197 UNCLOS 1982 menyebutkan perlunya "memperhitungkan fitur-fitur regional yang khas" dalam tugas negara-negara untuk membuat dan menguraikan aturan-aturan untuk tata kelola lingkungan laut. The United Nations Environment Programme (UNEP) menjalankan mandatnya melalui platform regional yang biasanya mencakup berbagai sistem politik, ekonomi, dan ekologi. Meskipun demikian, tidak ada konsensus umum tentang apa bentuk wilayahnya, atau siapa yang membuat tata kelola aturan lingkungan laut. Sejumlah faktor geografi, sejarah bersama, atau ketergantungan perdagangan dan ekonomi memotivasi negara-negara untuk menangani isu-isu tertentu di tingkat regional. Selain itu, ketika negara-negara mengidentifikasi sebagai pemilik suatu wilayah, mereka melakukannya dengan cara yang berbeda. ${ }^{13}$

Mahkamah Internasional memperkenalkan prinsip 'perpanjangan alami' landas kontinen yang juga merupakan atribut geofisika dari landas kontinen yang bersangkutan untuk penggambaran antar negara. Meskipun Mahkamah Internasional menetapkan bahwa 'tidak ada batasan hukum' untuk sejumlah faktor yang relevan dengan penetapan batas landas kontinen, faktor-faktor ini pada awalnya didefinisikan sebagai geologi, keinginan untuk mempertahankan kesatuan cadangan sumber daya alam, dan proporsionalitas (rasio antara air dan daerah paparan yang dikaitkan dengan masing-masing negara bagian dan panjang garis pantainya). ${ }^{14}$

Mengenai landas kontinen vis-à-vis ZEE, pada awalnya, aturan/proses untuk menyelesaikan kedua jenis batas tersebut berbeda. Penekanan pada 'perpanjangan alami' dan elemen ilmiah untuk membuktikannya melibatkan penggunaan pendekatan yang berbeda untuk delimitasi landas kontinen. Namun, karena praktik negara dan putusan pengadilan berkembang setelah Kasus the North Sea Continental Cases 1969, prinsip perpanjangan alami kehilangan pegangannya. Alasan utamanya adalah pengenalan konsep 200-n.m. dalam UNCLOS 1982 untuk jarak delimitasi landas kontinen dan ZEE, di mana negara, terlepas dari fitur kapal selam, segera memperoleh hak atas dasar laut dan kolom air hingga 200 n.m. dari pantai. Dengan aturan baru di UNCLOS 1982 dan beralih dari 'perpanjangan alami' sebagai dasar hak

12 Case Concerning Sovereignty Over Pulau Ligitan And Pulau Sipadan (2002).

13 Alexis Ian P. Dela Cruz, "A South China Sea Regional Seas Convention," The Journal of Territorial and Maritime Studies Vol. 6, no. 1 (n.d.): 5-29.

14 Andreas Østhagen, "Maritime Boundary Disputes: What Are They and Why Do They Matter?," Marine Policy 120 (2020), https:/ / doi.org/10.1016/j.marpol.2020.104118.

82 | B A L OBE Law Journal Vol. 1 No. 2, Oktober 2021 
atas landas kontinen, pengadilan telah mengadopsi pendekatan seragam untuk delimitasi batas maritim untuk kolom air dan dasar laut. ${ }^{15}$

Pertanyaan yang muncul dari konsep natural boundary adalah apakah eksistensi dari natural boundary yang membagi landas kontinen yang berbeda atau rezim ekologi tersebut relevan dengan delimitasi landas kontinen, atau ZEE, atau dengan zona perikanan dari negara tetangga. Dalam konteks delimitasi landas kontinen, teori natural boundary pada awalnya mendapat banyak masalah, setelah itu ditemukan bahwa jika ada "a marked disruption or discontinuance of the seabed as to constitute an indisputable indication of the limits of two separate continental shelves, or two separate natural prolongation". Maka prinsip natural boundary atau natural prolongation menjadi relevan. Akan tetapi, perpanjangan teori dari natural boundary pada delimitasi perikanan dan ZEE menemui kesulitan yang tidak dapat diatasi. Para sarjana menyatakan opini yang berbeda. Yang berpendapat positif, diantaranya yaitu Evans menyatakan bahwa ketika kolom air terlibat, maka baik sebagai elemen ZEE ataupun sebagai komponen single maritime boundary, "there is the possibility that it might provide a natural boundaries." Sebaliknya, Weil secara total menolak validitas dari natural boundaries di kolom air: "A flat, continuous ocean, offering an unimpeded means of communication, cannot admit of natural interruption," 16

Contoh kasus yang mempergunakan argumen natural prolongation tercermin pada kasus berikut. Dalam kasus Gulf of Maine tahun $1984,{ }^{17}$ para hakim menolak argumen ilmiah Amerika yang didesain untuk menjustifikasi natural prolongation sepanjang the Northeast Channel. Dengan garis tersebut maka akan memberikan yurisdiksi kepada Amerika atas seluruh Georges Bank, yaitu area besar di dasar laut yang memisahkan Teluk Maine dari Samudra Atlantik dan terletak di antara Cape Cod, Massachusetts (AS) dan Pulau Cape Sable, Nova Scotia (Kanada). Didorong oleh konsep yang dibuat oleh Mahkamah Internasional mengenai natural prolongation, Amerika menyadari (demikian juga Kanada) bahwa dasar laut teluk tersebut membentuk single uniform shelf maka sebagai konsekuensinya Northeast Channel bukan merupakan fitur geologi yang signifikan di dasar laut.

\section{Pembangunan Berkelanjutan (Principle of sustainable development)}

Abad 21 adalah abad lautan. Pola politik internasional sedang mengalami perubahan besar. Pentingnya lautan dalam politik internasional, ekonomi, keamanan, ilmu pengetahuan, teknologi, dan bidang lainnya, semakin meningkat dari hari ke hari. Perselisihan kedaulatan teritorial dan delimitasi batas laut menjadi semakin akut, yang mempengaruhi hubungan antar Negara. Di tingkat regional, kerjasama dan persaingan hidup berdampingan di bidang kelautan, yang erat kaitannya dengan perdamaian dan stabilitas kawasan. Di tingkat global, sikap di sekitar aturan laut baru semakin intensif dan pembangunan serta pemanfaatan laut yang damai, adil dan

15 Østhagen.

16 Sharma, "Relevance of Environmental and Security Considerations to the Delimitation of Maritime Boundaries."

17 Donat Pharand, "Delimitation of Maritime Boundaries: Continental Shelf and Exclusive Economic Zone, in Light of the Gulf of Maine Case, Canada v. U.S.A. (1984)," Revue Générale de Droit 16, no. 2 (2019), https:/ / doi.org/10.7202/1059297ar.

$83 \mid$ B A LOBE Law Journal Vol.1 No. 2, Oktober 2021 
berkelanjutan sangat penting. ${ }^{18}$

Ide tentang pembangunan berkelanjutan ini telah menjadi standar praktek dalam semua sektor aktivitas ekonomi beberapa tahun belakangan ini, dengan menekankan pembangunan berkelanjutan melalui cara penyelenggaraan ekonomi yang dapat memenuhi kebutuhan manusia sambil menjaga masa depan. Konsep ini juga berkembang dalam bidang perikanan dan kehutanan serta sektor lainnya yang dapat diperbaharui, dengan ide agar dapat mencapai hasil yang berkelanjutan dari sumber daya alam.

Peran lingkungan yang saling berhubungan dalam penentuan delimitasi maritim semakin meningkat dengan adanya pendekatan terpadu terhadap sustainable development dalam hukum laut, sesuai dengan UNCLOS 1982 dan Agreement Part IX tahun 1994. Serta sesuai dengan kerangka kerja Rio Declaration tahun 1992 dan dokumen lainnya di dalam the United nations Conference on Environment and Development (UNCED), sebagaimana diperkuat lagi dalam the 2000 United Nations Millenium Declaration dan the 2002 Johanesburg Declaration and Plan of Implementation of the World Summit on Sustainable Development (WSSD). ${ }^{19}$

Konsep modern dari sustainable development dalam hukum laut telah menjadi bagian dari hukum lingkungan internasional. Perkembangan tersebut tampak secara jelas pada tahun 1997 pada Putusan kasus Gabcikovo-Nagymaros Project, proses keseluruhan delimitasi perbatasan maritim yang equitable dan semua keadaan (circumstances) yang ditekankan dan diandalkan dalam proses tersebut, harus diartikan sebagai kontribusi terhadap pemeliharaan dan perlindungan lingkungan laut. $^{20}$

Pendekatan ini tercermin dalam Preamble dari Barbados-Guyana EEZ Cooperation Treaty tahun 2003, dalam preamble itu menekankan isi Konvensi 1982 "fundamental importance for the maintenance and strenghtening of international peace and security, as well as for the sustainable development of the oceans and seas." Pencerminan kesadaran para pihak dalam perjanjian itu tersirat dalam kalimat: "the need to agree upon the environmentally responsible management and the sustainable development of living and nonliving natural resources" di wilayah yang tumpang tindih dalam klaim ZEE kedua negara itu. Pada saat yang bersamaan, selain melanjutkan tradisi yang ada dalam perjanjian delimitasi di wilayah Karibia, perjanjian yang dilakukan oleh Barbados dengan Guyana juga mengadopsi peraturan yang sesuai dengan kewajiban internasionalnya, seperti UNCLOS 1982 dan UNEP Cartagena de Indias Convention mengenai semua peraturan yang diperlukan untuk pelestarian dan perlindungan lingkungan laut. Tradisi lingkungan di Karibia sendiri nampak di dalam saran proposal dari OAS Belize/Guatemala tahun 2002 untuk mendirikan Belize/Guatemala/Honduras Ecological Park sebagai bagian dari maritime boundary

18 Yue Sun et al., "The Construction and Governance of Regional Maritime Security Order in the South China Sea: Conference Report," in Marine Policy, vol. 126, 2021, https://doi.org/10.1016/j.marpol.2021.104438.

19 Kwiatkowska, "Economic and Environmental Considerations in Maritime Boundary Delimitation."

20 “Gabcikovo-Nagymaros Project Judgement," 1997. 
resolution. ${ }^{21}$

\section{Sumber Daya Mineral}

Sumber daya mineral merupakan salah satu pertimbangan penting dalam penetapan delimitasi, terutama di rezim landas kontinen. Mengingat semakin tinggi kebutuhan akan mineral dan semakin berkurangnya sumber alam yang telah dieksploitasi maka perlu bagi suatu negara untuk mendapatkan cadangan sumber daya mineral baru untuk masa akan datang. Terkait dengan proses delimitasi maka para negosiator dalam proses delimitasi harus dapat memastikan bahwa wilayah yang akan dilakukan delimitasi itu mengandung sumber daya mineral atau tidak, hal ini dapat dilakukan dengan serangkaian penelitian terkait. Jika diduga kuat atau sudah diketahui dengan pasti wilayah yang akan didelimitasi mengandung mineral maka hal ini dapat menjadi bahan pertimbangan yang mempengaruhi jalannya negosiasi.

Banyak perjanjian perbatasan yang mengandung ketentuan yang berkaitan dengan sumber daya alam. Beberapa batas landas kontinen dan delimitasi maritim serbaguna (multipurpose maritime delimitations) juga memuat specific resource deposit clause, dan joint development arrangements yang mengatur mengenai unitization atau kerjasama lainnya. ${ }^{22}$

Resources deposit clauses dibuat oleh suatu negara dengan tujuan untuk bekerja sama ketika terdapat suatu sumber alam tunggal yang terletak diantara dua negara dan melewati perbatasan dan bagian dari sumber alam itu dapat dieksploitasi disisi perbatasan negara lain. Skema joint development menetapkan pengaturan kerjasama antar negara untuk mengeksplorasi dan eksploitasi mineral yang terletak di daerah yang melewati batas negara atau di daerah klaim tumpang tindih. Hal ini yang menunjukkan perbedaan antara Joint development dengan unitization, dimana unitization melibatkan kontrak kerjasama antara licensees/concessionaires di area yang melewati garis antara concession areas (block). ${ }^{23}$

Dalam banyak situasi, dapat disimpulkan bahwa kepentingan utama negaranegara yang berkaitan dengan delimitasi di zona diluar laut teritorial, seperti ZEE, BLK dan zona perikanan selalu berkaitan dengan keuntungan ekonomi yang didapat dari eksploitasi sumber daya alam di zona maritim tersebut, baik itu sumber daya hayati ataupun nonhayati. Oleh karena itu, tidaklah mengherankan selain faktor geografi dan geofisik, perhatian negara terhadap lokasi sumber daya alam di daerah yang akan didelimitasi sangat penting. Dalam beberapa kasus, tampak bahwa sumber daya alam telah memberikan dorongan dibelakang jalannya negosiasi dan menghasilkan banyak perjanjian perbatasan maritim. ${ }^{24}$

Sumber daya alam khususnya kandungan minyak bumi, gas dan perikanan

21 Jon M. Van Dyke, “David A. Colson and Robert W. Smith, Eds., International Maritime Boundaries Volume VI," Ocean Yearbook Online 26, no. 1 (2012), https://doi.org/10.1163/2211600190000073.

22 Kwiatkowska, "Economic and Environmental Considerations in Maritime Boundary Delimitation."

${ }^{23}$ Kwiatkowska.

${ }^{24}$ Handbook on the Delimitation of Maritime Boundaries, Handbook on the Delimitation of Maritime Boundaries, 2000, https:/ / doi.org/10.18356/cc72cd88-en. 
dapat mempengaruhi delimitasi dengan dua cara, yaitu:

1) Langsung mempengaruhi jalannya garis batas yang diadopsi; atau

2) Sebagai objek pengaturan antara kedua belah pihak yang memfasilitasi pengadopsian garis delimitasi berdasarkan pertimbangan-pertimbangan lain seperti faktor geografi.

Sebagai contoh, terdapat beberapa kasus dimana garis delimitasi disesuaikan agar mengikuti lokasi ladang minyak, seperti dalam perjanjian Bahrain-Saudi Arabia tahun 1958 yang diaplikasikan pada sepertiga garis terakhir di lokasi ladang minyak Fasht Abu-Sa'fah. ${ }^{25}$ Permasalahan sumber daya mineral dapat ditangani dengan memasukkan satu atau beberapa ketentuan kerjasama antara para pihak untuk mengeksploitasi deposit yang terletak diantara garis delimitasi, kedalam perjanjian delimitasi. Pemecahan ini dapat diadopsi ketika telah diketahui pasti terdapat deposit yang berada diantara garis delimitasi atau juga dalam kasus dimana terdapat penemuan yang berpotensi terhadap deposit sumber daya alam di masa akan datang.

\section{Perikanan}

Saat ini ditengarai produksi perikanan negara-negara pantai semakin berkurang. Banyak faktor yang berkontribusi terhadap kondisi yang menyedihkan ini. Diantaranya adalah peningkatan dalam teknologi penangkapan ikan, ditambah dengan subsidi pemerintah yang besar untuk nelayan, sehingga menyebabkan pesatnya peningkatan kapasitas panen. Pada saat yang sama, degradasi lingkungan merusak beberapa habitat ikan. Namun penangkapan ikan untuk industri dan para pembuat kebijakan secara konsisten mengabaikan seruan dari ilmuwan untuk melakukan tindakan konservasi ketat yang harus diikuti baik di dalam dan di luar ZEE (Zona Ekonomi Eksklusif).

Dalam perkembangan di masyarakat internasional, kerangka hukum internasional telah ada untuk membangun respon terhadap krisis perikanan yaitu melalui UNCLOS 1982. Bahkan sebelum Konvensi mulai berlaku pada tahun 1994 sebagian besar negara telah menerima ketentuan-ketentuan perikanan sebagaimana cerminan hukum kebiasaan internasional. Ketentuan-ketentuan hukum internasional yang sudah ada sebelumnya berubah secara signifikan dalam beberapa cara, yang paling penting melalui legitimasi dari ZEE sampai jarak 200 mil lepas pantai, di mana negara-negara pantai memiliki kontrol penuh atas perikanan. Karena lebih dari 90 persen semua panen laut dilakukan di wilayah dalam radius 200 mil, UNCLOS 1982 secara efektif menempatkan sebagian besar sumber daya laut hidup dibawah pengaturan hak yurisdiksi negara pantai.

Karena mendapat manfaat yang besar ini maka sebagai gantinya negara pantai memiliki tugas-tugas tertentu. Setiap negara pantai harus menentukan sumber daya tangkapan yang diperbolehkan diwilayah ZEE-nya; melindungi sumber daya tersebut terhadap eksploitasi yang berlebihan; mengambil langkah tertentu untuk mengurangi penangkapan; mempromosikan pemanfaatan optimal sumber daya tersebut; dan menentukan kapasitasnya untuk memanen sumber daya tersebut, serta memberikan hak kepada negara lain akses untuk menangkap surplus perikanan.

${ }^{25}$ Handbook on the Delimitation of Maritime Boundaries.

$86 \mid$ B A LOBE Law Journal Vol. 1 No. 2, Oktober 2021 
Mengenai penegakan hukum, konvensi memberikan wewenang masing-masing negara pantai untuk mengatur hukum perikanan di dalam ZEE terhadap setiap kapal yang mungkin memancing di sana. Kapal penangkap ikan di laut lepas, sebaliknya, tetap berada di bawah yurisdiksi eksklusif negara bendera, meskipun negara bendera mungkin menyetujui tindakan penegakan hukum oleh negara lain baik melalui perjanjian atau atas dasar ad hoc. Hukum perikanan internasional telah demikian jelas menarik garis di lautan - garis 200 mil - membagi ZEE dari laut lepas. Di dalam garis ZEE, negara pantai memiliki otoritas penuh atas kegiatan perikanan, tunduk pada kewajiban umum untuk melestarikan dan untuk mengalokasikan surplus ikan untuk negara lain. Di luar garis ZEE, semua negara dapat menangkap ikan, tergantung pada pembatasan tertentu, termasuk kewajiban untuk melestarikannya.

Laporan perbatasan membuktikan bahwa perikanan memainkan peran penting dalam sejumlah negosiasi delimitasi sebagai faktor penyerta dan terkait dengan penyelesaian permasalahan delimitasi. Secara khusus akomodasi kepentingan perikanan dan secara khusus yaitu aktifitas perikanan tradisional para pihak, memainkan peran baik sebagai elemen persetujuan selama negosiasi perjanjian atau terkadang sesaat sebelum penyelesaian, atau saat setelah penyelesaian delimitasi maritim, atau sebagai ukuran yang diambil dalam menunggu penyelesaian. ${ }^{26}$

Peran perikanan nampak jelas dalam perjanjian perbatasan antara Kanada dengan Perancis (St. Pierre and Miquelon) tahun 1972 yang berkaitan dengan laut teritorial dan yurisdiksi perikanan. Perjanjian antara Swedia dengan USSR tahun 1988 dan India dengan Srilanka tahun 1976 yang berkaitan dengan multipurpose boundaries. Di wilayah Laut Merah, perjanjian antara Eritrea-Yaman tahun 1999 menyatakan dengan menghormati aspek lingkungan dari "perpetuation of the traditional fishing regime" sehingga semua ketentuan administratif yang mempengaruhi rezim perikanan harus diputuskan oleh Yaman melalui perjanjian dengan Eritrea dan sejauh yang berkaitan dengan akses melewati perairan Eritrea ke pelabuhannya. ${ }^{27}$

Pada tanggal 9 Juni 2020, Yunani dan Italia menandatangani di Athena perjanjian delimitasi maritim di Laut Ionia, diselesaikan dengan proposal bersama Yunani-Italia kepada Komisi Eropa untuk modifikasi Lampiran 1 Kebijakan Perikanan Bersama dan deklarasi sumber daya dari Mediterania. Persetujuan ini mengadopsi garis delimitasi landas kontinen yang disepakati pada tahun 1977 untuk delimitasi zona-zona lain yang menjadi hak kedua negara berdasarkan Hukum Internasional. Ini membahas kepentingan mendasar kedua negara: kepentingan penangkapan ikan penting Italia dan masalah hukum dan politik Yunani terkait dengan perselisihan setengah abad dengan Turki mengenai delimitasi maritim di Laut Aegea dan Mediterania Timur. ${ }^{28}$ Berdasarkan beberapa contoh delimitasi di atas dapat disimpulkan bahwa peran perikanan merupakan salah satu faktor yang berpengaruh dalam penentuan

26 Kwiatkowska, "Economic and Environmental Considerations in Maritime Boundary Delimitation."

${ }^{27}$ Van Dyke, "David A. Colson and Robert W. Smith, Eds., International Maritime Boundaries Volume VI."

${ }^{28}$ Aris Marghelis, "The Maritime Delimitation Agreement between Greece and Italy of 9 June 2020: An Analysis in the Light of International Law, National Interest and Regional Politics," Marine Policy 126 (2021), https:/ / doi.org/10.1016/j.marpol.2021.104403.

87 B A L OBE Law Journal Vol. 1 No. 2, Oktober 2021 
delimitasi perbatasan maritim antar negara.

\section{P E N U T U P}

Berdasarkan pemaparan faktor lingkungan dan delimitasi di atas maka dapat ditarik beberapa kesimpulan, antara lain adalah: meskipun perannya lebih kecil jika dibandingkan dengan faktor geografi, navigasi, sosial, politik, teknologi dan ekonomi namun faktor lingkungan juga memiliki pengaruh dalam penentuan perjanjian delimitasi maritim. Hubungan antara faktor lingkungan dengan proses delimitasi terjadi dengan dua cara: Pertama, pertimbangan lingkungan menunjukkan pengaruh langsung dalam pemilihan metode delimitasi. Disini faktor lingkungan merupakan motif yang penting dalam proses delimitasi. Beberapa perjanjian mengandung ketentuan khusus dan/atau disertai pengaturan mengenai pertimbangan lingkungan. Kedua, faktor lingkungan mempengaruhi proses delimitasi secara tidak langsung, di mana ada sejumlah perjanjian yang tidak mencantumkan secara spesifik ketentuan mengenai lingkungan, tapi bukti-bukti menunjukkan bahwa para pihak dimotivasi oleh faktor lingkungan dalam melakukan negosiasi delimitasi. Faktor lingkungan memainkan peran baik sebagai elemen persetujuan selama negosiasi perjanjian atau terkadang sesaat sebelum penyelesaian, atau saat setelah penyelesaian delimitasi maritim, atau sebagai ukuran yang diambil dalam menunggu penyelesaian. Selain itu, terdapat juga perjanjian yang tidak melibatkan sama sekali faktor lingkungan dalam perjanjian perbatasannya. Beberapa faktor dalam hukum lingkungan yang pernah dijadikan alasan dalam argumen untuk menentukan delimitasi maritim oleh suatu negara antara lain adalah: faktor konservasi suaka margasatwa, prinsip perpanjangan alami, prinsip sustainable development, sumber daya mineral, perikanan, dan single state management theory. Fungsi lingkungan dalam proses delimitasi yaitu untuk mengatur sumber kekayaan serta aktivitas ekonomi yang berhubungan dengan perbatasan, dan untuk memfasilitasi delimitasi perbatasan dengan membedakan isu lingkungan dari penarikan garis perbatasan secara aktual. Di sisi lain, pengaturan standar lingkungan memiliki kesulitan-kesulitan yang khusus, yang tidak ada di dalam kasus delimitasi maritim. Pertama; standar lingkungan berubah-ubah, sedangkan perbatasan maritim sekali sudah ditetapkan maka jarang berubah. Sebagai contoh yaitu penggunaan prinsip natural prolongation pada awalnya diterima sebagai salah satu konsep dalam delimitasi namun seiring dengan waktu maka konsep tersebut telah tersisih dalam hukum laut internasional. Hal ini menunjukkan bahwa konsep yang berkaitan dengan lingkungan bukan sesuatu yang ajeg dan dapat berubah seiring dengan perkembangan jaman. Kedua; pengaturan standar lingkungan menghasilkan pertimbangan kebijaksanaan yang luas dibandingkan delimitasi maritim yang merupakan proses mencari tahu batas yang sudah mapan dan hanya khusus di lokasi tertentu dari perbatasan maritim. Standar lingkungan ini dapat dipergunakan di dalam berbagai bidang karena hampir semua kegiatan manusia memiliki keterkaitan dengan lingkungan, jadi tidak hanya secara spesifik berhubungan dengan delimitasi maritim semata.

\section{REFERENSI}

Acikgonul, Yunus Emre, and Edward R. Lucas. “Developments in Maritime Delimitation Law over the Last Decade: Emerging Principles in Modern Case 
Law." Canadian Yearbook of International Law 45, no. 3 (2020). https://doi.org/10.1017/cyl.2020.9.

Arbitral award relating to the issue of control and sovereignty over Aves island, raised between Venezuela and the Kingdom of the Netherlands (n.d.).

Case Concerning Sovereignty Over Pulau Ligitan And Pulau Sipadan (2002).

Charney, Jonathan I. "Ocean Boundaries between Nations: A Theory for Progress." American Journal of International Law 78 (1984).

Cruz, Alexis Ian P. Dela. “A South China Sea Regional Seas Convention." The Journal of Territorial and Maritime Studies Vol. 6, no. 1 (n.d.): 5-29.

Dyke, Jon M. Van. "David A. Colson and Robert W. Smith, Eds., International Maritime Boundaries Volume VI." Ocean Yearbook Online 26, no. 1 (2012). https://doi.org/10.1163/22116001-90000073.

“Gabcikovo-Nagymaros Project Judgement," 1997.

Handbook on the Delimitation of Maritime Boundaries. Handbook on the Delimitation of Maritime Boundaries, 2000. https:// doi.org/10.18356/cc72cd88-en.

Hansen-Magnusson, Hannes. "The UN Convention on the Law of the Sea." In International Relations as Politics among People, 2020. https://doi.org/10.4324/9780429197413-4.

“I.C.J Reports," 1984.

Ikporukpo, Christ O. "Boundaries and Natural Resources in the Sea." The Journal of Territorial and Maritime Studies Vol 7, no. 2 (2020): 103-27.

Kwiatkowska, Barbara. "Economic and Environmental Considerations in Maritime Boundary Delimitation." In International Maritime Boundaries, edited by Jonathan I. Charney and Lewis M. Alexander. Netherlands: Martinus Nijhoff Publishers, 1996.

Marghelis, Aris. “The Maritime Delimitation Agreement between Greece and Italy of 9 June 2020: An Analysis in the Light of International Law, National Interest and Regional Politics." Marine Policy $126 \quad$ (2021). https://doi.org/10.1016/j.marpol.2021.104403.

Ndiaye, T.M., and R Wolfrum. Law of the Sea, Environmental Law and Settlement of Disputes. Leiden/Boston: Martinus Nijhoff Publishers, 2007.

Østhagen, Andreas. "Maritime Boundary Disputes: What Are They and Why Do They Matter?” Marine Policy 120 (2020). https:/ / doi.org/10.1016/j.marpol.2020.104118.

Pharand, Donat. "Delimitation of Maritime Boundaries: Continental Shelf and Exclusive Economic Zone, in Light of the Gulf of Maine Case, Canada v. U.S.A. (1984)." Revue Générale de Droit 16, no. 2 (2019). https:// doi.org/10.7202/1059297ar.

Sharma, Surya P. "Relevance of Environmental and Security Considerations to the Delimitation of Maritime Boundaries." In Law, Social Sciences and Public Policy Towards a Unified Framework, edited by Anthony Chin and Alfred Choi. Singapore: 
Singapore University Press, 1998.

Sun, Yue, Yang Han, Liangfu Zhang, and Yen Chiang Chang. “The Construction and Governance of Regional Maritime Security Order in the South China Sea: Conference Report." In Marine Policy, Vol. 126, 2021. https://doi.org/10.1016/j.marpol.2021.104438. 